\title{
小児歯科領域におけるレーザー治療の応用
}

\author{
加 藤 純 二 \\ 東京医科歯科大学大学院医歯学総合研究科 \\ 摂食機能保存学講座う蝕制御学分野 \\ (受付 : 2009 年 7 月 31 日, 受理 : 2009 年 8 月 31 日)
}

\section{Application of Laser Treatment in Pediatric Dentistry}

\author{
Junji KATO \\ Cariology and Operative Dentistry,Department of Restorative Sciences, \\ Graduate School, Tokyo Medical and Dental University \\ (Received: July 31, 2009, Accepted for Publication: August 31, 2009)
}

\begin{abstract}
Treatment methods in pediatric dentistry must be painless, safe, and relatively short to avoid fear in the patient and allow convenient postoperative healing. Laser treatment satisfies these criteria, making it very effective for pediatric patients. Low level lasers such as the He-Ne laser, diode laser and Nd:YAG laser are currently used for pulp therapy to accelerate pulp wound healing, whereas the $\mathrm{CO}_{2}$ laser and Nd:YAG laser are used for dental caries prevention by making enamel acid resistant. The $\mathrm{CO}_{2}$ laser is mainly used for soft tissue problems because hemostasis can be achieved rapidly during surgery and the patient experiences good wound healing with little or no postoperative pain. The Er:YAG laser allows preparation of a cavity without pain by ablation of dental hard tissue. In this paper, we discuss the effectiveness of laser therapy for pediatric patients in clinical procedures from deciduous dentition to permanent dentition.
\end{abstract}

(J. Jpn. Soc. Laser Dent. $20: 135 \sim$ 141, 2009 Reprint requests to Dr. KATO)

Key words $=$ Laser, Pediatric dentistry, Painless treatment

キーワードニレーザー, 小児歯科, 無痛治療

\section{緒言}

小児歯科とは特定の歯科疾患を専門とするのではなく, 小児の保存治療から外科処置まですべてを取り扱う診療科 であるため，最も多岐にわたってレーザーが活用される分 野といえる。現在, He-Ne レーザー（波長 $630 \mathrm{~nm}$ ), 半導 体レーザー（波長 810nm）, Nd:YAG レーザー（波長 1.064 $\mu \mathrm{m})$, Er:YAGレーザー（波長 $2.94 \mu \mathrm{m} ）$, 炭酸ガスレー ザー（波長 $10.64 \mu \mathrm{m} ）$ などが臨床応用されているが, 小 児歯科領域ではこれらの全てのレーザーの特長が生かされ ている1)。低出力での He-Ne レーザー, 半導体レーザー, Nd: $Y A G$ レーザーは, その創傷治癒促進効果を利用し覆 髄法や歯髄切断法などに使用され, またNd:YAGレー ザーや炭酸ガスレーザーでは䶚蝕予防効果が実証されてい る。さらに炭酸ガスレーザーでは, 蒸散効率の高さと随伴
する熱障害の少なさから舌小帯強直症や粘液囊胞などの軟 組織疾患に対する外科的処置においても治療効果を上げて いる。Er:YAGレーザーでは, エナメル質を含めた硬組織 の安全な切削や䠘蝕除去が可能である。

一方, 小児期は人の一生の中で最も成長著しい時期であ り, 良くも悪くもこの時期の口腔環境がその人の一生の口 腔状態を左右するといっても過言ではない。健全な永久歯 列を獲得し, 維持していくためにも適切な治療と管理が求 められる時期である。

本論文では, レーザーの応用法を, 無歯顎での誕生から 永久歯列完成までを大きく3つのステージに分けて考え る。まず乳歯列の完成まで, 続いて永久歯との交換期であ る混合歯列期, 最後に永久歯列完成期である。ステージご とに，それぞれの時期における治療目標と，その時期に見 合ったレーザーの応用法についてまとめる。

干 113-8549 東京都文京区湯島 1-5-45 TEL 03-5803-5483 FAX 03-5803-0195

1-5-45 Yushima, Bunkyo-ku, Tokyo 113-8549, Japan. TEL +81-3-5803-5483 FAX + 81-3-5803-0195 


\section{乳歯列期}

乳歯列期の一つの大きな目標は, 永久歯が萌出する前, それも第一大臼歯萌出前に, カリエスリスクを最小限にす ることである（図 1）。主な処置は未処置歯をなくすこと と, その後の管理ということになる。う蝕処置のポイント は二つで，まず確実性の高い処置であること，例えば，何 度も脱離を繰り返すような修復は避ける必要がある。もう

\section{- 永久歯萌出前に口腔衛生環境を整える}

1. 䠛蝕歯への対応

- 確実性の高い奶置

- 正しい萌出位置への誘導

\section{2. 定期管理-予防} (特に第一大臼歯)

\section{- 口腔機能の発育を促す} 一舌小带への対応

\section{・低年齢児の取り扱い}

- 不意な動き

一痛み
一つは, 永久歯の正しい萌出位置への誘導, これは, 永久 歯の萌出位置を狂わせる要因はなるべく作らない，という ことになる。また, 同時にこの時期には舌小帯への対応, それから患児の協力度に対する配慮も必要である。

1. う蝕処置と Er:YAG レーザー

まず，う蝕への対応である。図 2 のような第一乳臼歯と 第二乳白歯間の隣接面う蝕は, 乳歯ではよくみられるが, 歯髄処置に移行することのないよう確実な処置が望まれ る。そのためには，軟化象牙質をとり残さないこと，ま た，乳歯は永久歯に比べて歯質が薄く，特に第一乳臼歯な どで䯣角が発達しているので, 適宜覆䯣処置を行うことが 大切である（図 2)。丁寧な充填操作で窩洞辺縁を確実に 封鎖することが，二次う蝕の発生を防ぐ意味でも重要であ る。

コンポジットレジンによる直接修復の多い小児のカリエ スにとって，Er:YAG レーザーは有用性が高いレーザーで ある2,3)。切削時の騒音, 振動が少ないことや, タービン より噴霧される水量が少ないことも低年齢児の治療におい て有用である。Er:YAGレーザーは，エネルギーのほとん どが水に吸収されるため，硬組織中のわずかな水分子やそ の周囲の水分子が瞬間的に気化し，微小爆発が生じること により切削が進むと言われている(-6)。レーザーによるエ ナメル質の切削は永久歯ではエアータービンより比べると
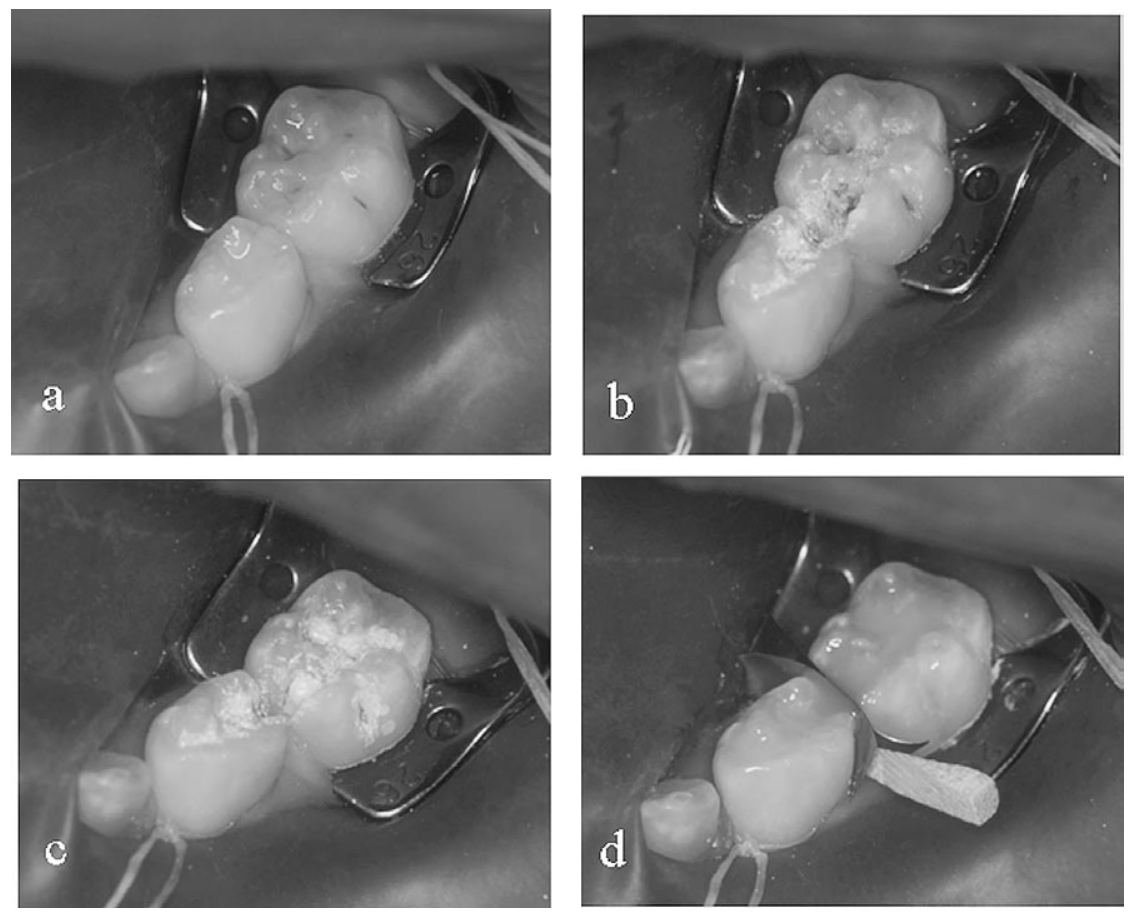

図 2 う蝕処置 $(3$ 歳

a. 術前：下顎第一，第二乳臼歯の咬合面およびその隣接面にう蝕が認められる。

b. う蝕除去後：Er:YAG レーザー（アーウィン，モリタ社）でう蝕を除去する。照射条件は，注水下で出力 $80-150 \mathrm{~mJ} / 10 \mathrm{pps}$

c. 歯髄保護：う窩の深いところや髄角相当部は歯髄保護を行う。

d. コンポジットレジン修復直後：確実な辺縁封鎖をおこなう。 

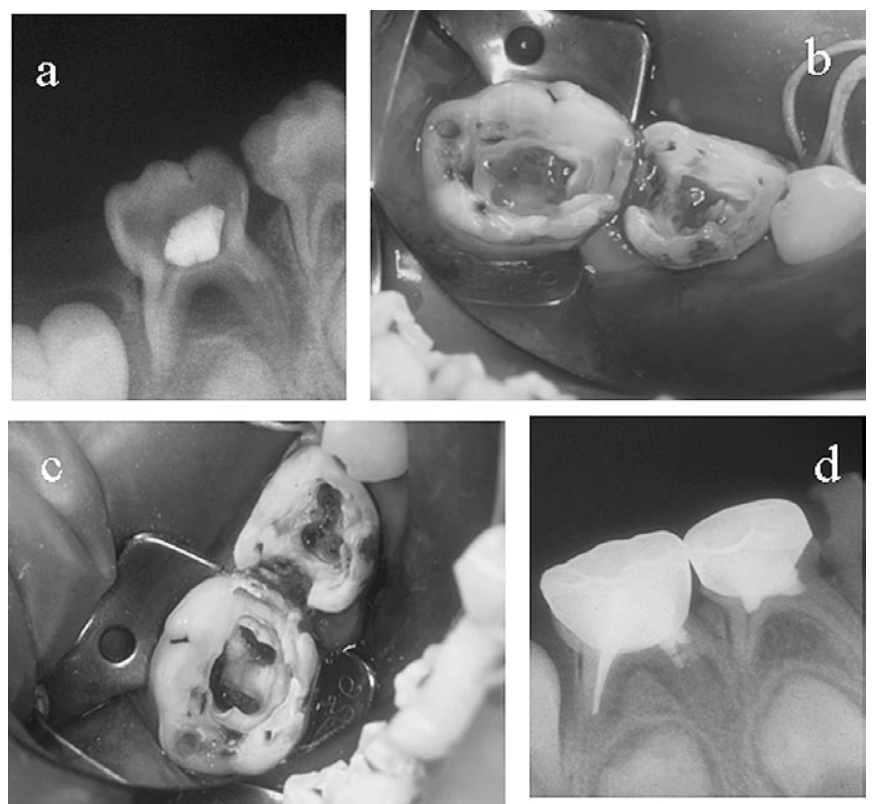

図 3 歯髄処置 (5 歳)

a. 術前のレントゲン像：下顎第二乳臼歯に歯髄処置が施されているが, 根分岐部に大きな X 線透過像が認められる。下顎第一乳臼歯 は遠心隣接面に髄角に至る部位にX 線透過像が認められる。

b. 根管口明示：麻酔下にエアータービンでう窩の開拡をおこない, 根管口を明示する。下顎第二乳白歯では, 根管内に易出血性の不 良肉芽組織がみられる。下顎第一乳白歯は歯冠部歯髄を除去した。

c. レーザー応用後：下顎第二乳臼歯は, Er:YAG レーザー（アーウィン，モリ夕社）（出力 $80 \mathrm{~mJ} / 10 \mathrm{pps}$ 注水なし）で根管内の不良 肉芽組織の除去をおこなう。レーザーを照射しながらファイリングをおこなうと効果的である。水酸化カルシウム製剂（ビタペッ クス，ネオ社）で根管充填を㧍こなう。第一乳臼歯は根管口部でレーザー照射し FC 断髄した。

d. 6 ケ月後のレントゲン像：下顎第二乳臼歯において根分岐部の透過像の消失が認められる。

時間がかかるが, 乳歯の場合は永久歯に比べてエナメル質 が薄く硬度も低いので, エアータービンとほぼ同程度の時 間で切削が可能である ${ }^{2,3)}$ 。

2. 歯内療法とレーザー

乳歯はう蝕の進行が早く歯髄処置にいたる場合が多い。 覆髄や断髄などの歯髄温存療法において, 歯䯣を活性化さ せ治癒力を促進する目的で, 低出力の Nd:YAG レーザー, 半導体レーザー, そして He-Ne レーザーの使用は有効で ある7,8)。修復象牙質あるいは庇蓋硬組織などの速やかな 形成が期待できる。

また, 乳歯の病的歯根吸収を伴った感染根管治療の際, レーザーの応用は効果的である。図 3 の症例では, 下顎第 二乳白歯は断䯣が施してあるが, 根分岐部に大きな透過像 がみられ，その遠心に第一大臼歯が近接している。下顎第 二乳白歯は抜歯の適用症例とも考えられるが, 第一大毛歯 の萌出が近い時期では, 第二乳臼歯の存在は第一大臼歯の 萌出位置を誘導する意味で重要であるため, 抜歯するか否 か悩むところとなる。歯根の吸収が進み感染病巣をもった 乳歯は, 不良肉芽組織が存在し, 易出血性で根管治療が難 しい。もし根管治療が可能なら第一大白歯の萌出完了ま で，第二乳白歯を一時的に保存することができる。このよ うな場合，丁寧なレーザー照射とファイリングを交互に行
うことによって，不良肉芽組織の除去が容易になり，止血 も得られ，根管充填が可能になる（図 3)。レーザーは透 過性のない蒸散効果の高い炭酸ガスレーザーや Er:YAG レーザーが使用しやすいが，直下に後継永久歯胚があるの で, 過度の高出力照射は厳禁である。そして, 乳歯の保存 は, 第一大臼歯の萌出後, 対合歯と咬合するまでを一つの 目標とする。

3. 舌小帯強直症への応用

舌小帯の異常は発音に影響することがある。そのため, 発音・構音機能の完成する前, すなわち就学直前に処置を 行うことが望ましい。図4 に示すとおり,レーザーを用い ると術式が簡単になる。術中の舌の固定はバキュームで十 分で, 縫合糸で舌尖を劧引する必要はない。また, 術中, 術後出血がほとんどなく, 縫合もほとんど必要ないため, 少量の麻醉ですみ, 短時間で治療がすむ。術後の痛みが少 ないのも特長のひとつである。種々のレーザーで応用可能 であるが，適度な止血効果の得られる炭酸ガスレーザーが 最も使いやすい99。

乳歯列期とは, 年齢的には未就学の乳幼児であり, 発達 の差が大きい時期である。多少の不快感があっても治療の ためと理解して我慢できるようになるのは，概ね年長園児 になってからである。それ以前の子どもでは痛みが非協力 

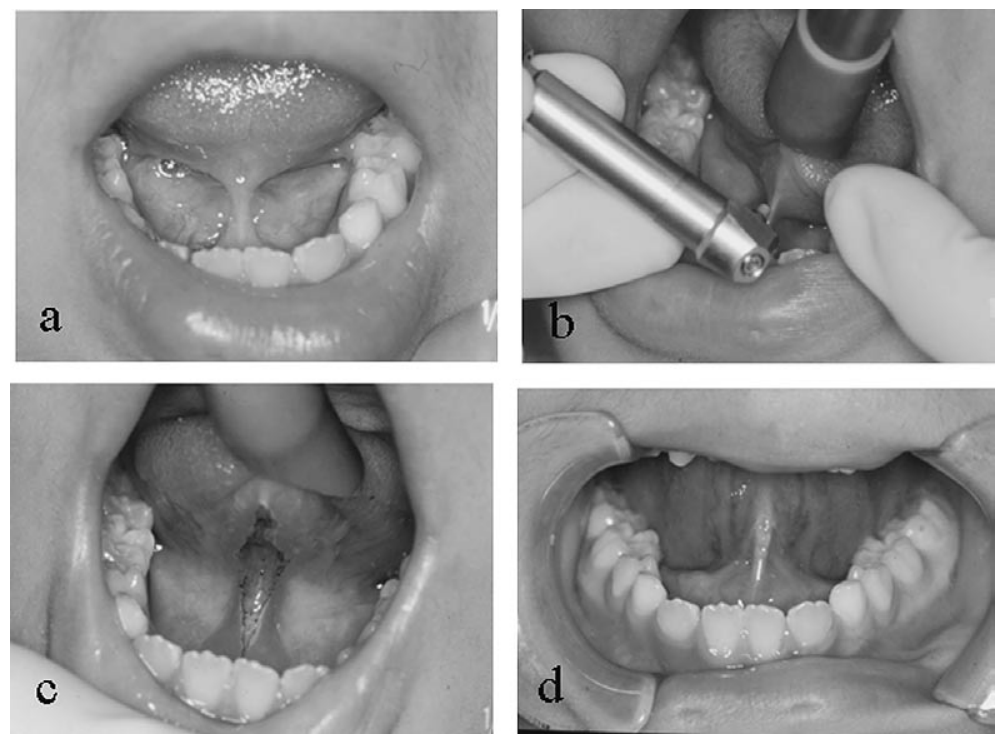

図 4 舌小帯切除 $(6$ 歳 $)$

a. 術前：舌小帯の短縮がみられ，舌を口蓋に接触させることができない。

b. 術中：局所麻酔下で, 炭酸ガスレーザー（ベルラクサー, タカラベルモント社）（連続波出力 2-3 W）で, 小帯を切除する。 バキュームチップで舌を吸引し固定する。

c. 術直後 : 創面には炭化層が一部認められるが, 出血はない。舌の上前方への伸展が可能になる。このケースでは縫合は不要。

d. 2 週後 : 創面はほぼ治癒し, 舌の伸展がみられる。

のトリガーとなるため，レーザー使用時の観血処置でも確 実な除痛（局所麻酔）が必要である。また，一見協力的な 子どもにみえても，急に手を振り払うなど，突発的な動作 をすることがあるので，特にレーザー照射時には注意が必 要である。

\section{混合歯列期}

この時期は永久歯の萌出期にあたり，全ての処置は永久 歯の保護を第一として考えておこなう（図 5 ）。特に萌出 途上の大臼歯はう蝕になりやすく, 積極的に予防を行う。 それに対してこの時期の乳歯は，いつ抜けるか，あるいは いつ抜くか，がポイントとなる。上唇小帯への対応はこの 時期に行い，粘液囊胞にもしばしば遭遇することがある。

\section{1. 䠛蝕予防}

第一大臼歯では, 萌出完了前のう蝕を高頻度に経験す る。特に遠心歯肉弁の残存は清掃不良をもたらし, 予防処 置が不完全なものになる。レーザーは, 歯肉弁の切除が容 易にでき，同時に歯質強化も可能である。

レーザーによる歯質強化は, 照射時の熱作用によって生 じるエナメル質の物理的な変化による ${ }^{10,11)}$ 。したがって, 歯にレーザーを照射するだけで効果が得られ，効果は不可 逆的で即効性がある，防湿などの準備を必要としない，短 時間の処置が可能である, 歯の萌出程度に関係なく適用で きる，などの利点がある。反面，熱作用により歯面に亀裂 や変色などを生じる場合もあるが，現在では，パルス波な ど余分な熱作用の少ない照射モードが普及し，そのような
・萌出途上大臼歯の保護 - 積極的予防

- 正しい永久歯配列への誘導 一後継永久歯に配慮した対応 一 上唇小帯人の対応

- 交換期に多い口腔軟組織疾患 - 粘液囊胞への対応

図 5 混合歯列期での目標

場合は少なくなってきている。また，レーザーによる歯質 強化は，健全歯だけでなく形成不全歯およびエナメル質減 形成を伴う歯面への応用も可能であり，初期䠛蝕に対する 再石灰化促進も期待できる ${ }^{12,13)}$ 。

炭酸ガスレーザーは，歯肉弁を効率よく切除でき，歯質 強化が得られる ${ }^{14)}$ (図 6)。Er:YAG レーザーの場合, 歯質 への照射は歯質が切削されるので歯質強化のみを目的とし た照射には不適である。また歯質透過性の高い $\mathrm{Nd}: \mathrm{YAG}$ レーザーや半導体レーザーは, 耐酸性の付与効果は高い が，歯質表面にレーザー光を吸収させるために照射時に墨 汁などの吸収性色素を歯面に塗布する必要がある ${ }^{10)}$ 。

2. 軟組織疾患

上唇小帯の切除は原則的にこの時期に行う。舌小帯の場 

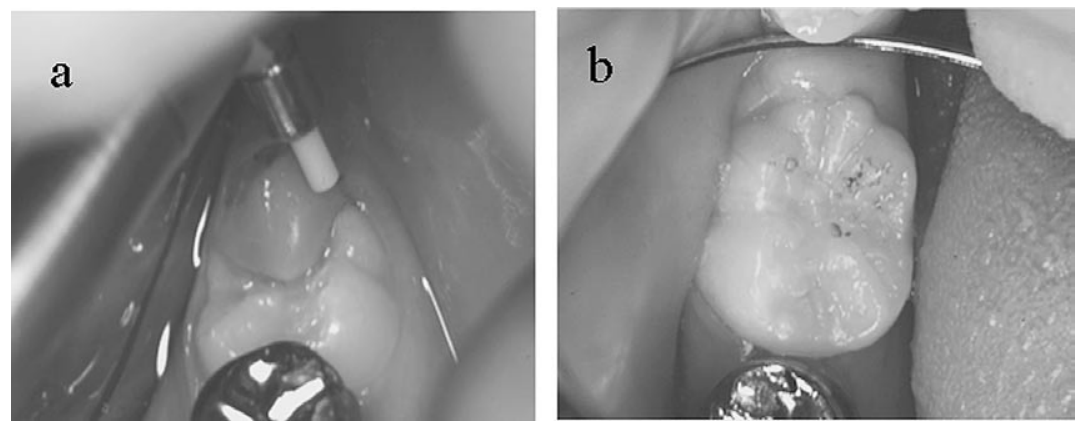

図 6 幼若永久歯のう蝕予防 $(6$ 歳 $)$

a. 術前：下顎第一大臼歯咬合面遠心に厚い歯肉弁が認められる。局所麻酔下に，炭酸ガスレー ザー（ベルラクサー， タカラベルモント社）（連続波出力 $3 \mathrm{~W} ）$ を用いて歯肉弁を切除する。そ の後，小窩裂溝に沿わせながらレーザー（エネルギー密度約 $25 \mathrm{~J} / \mathrm{cm}^{2}$ ) を歯質表面に照射した。

b. 3 年後：う蝕の発生は認められない。
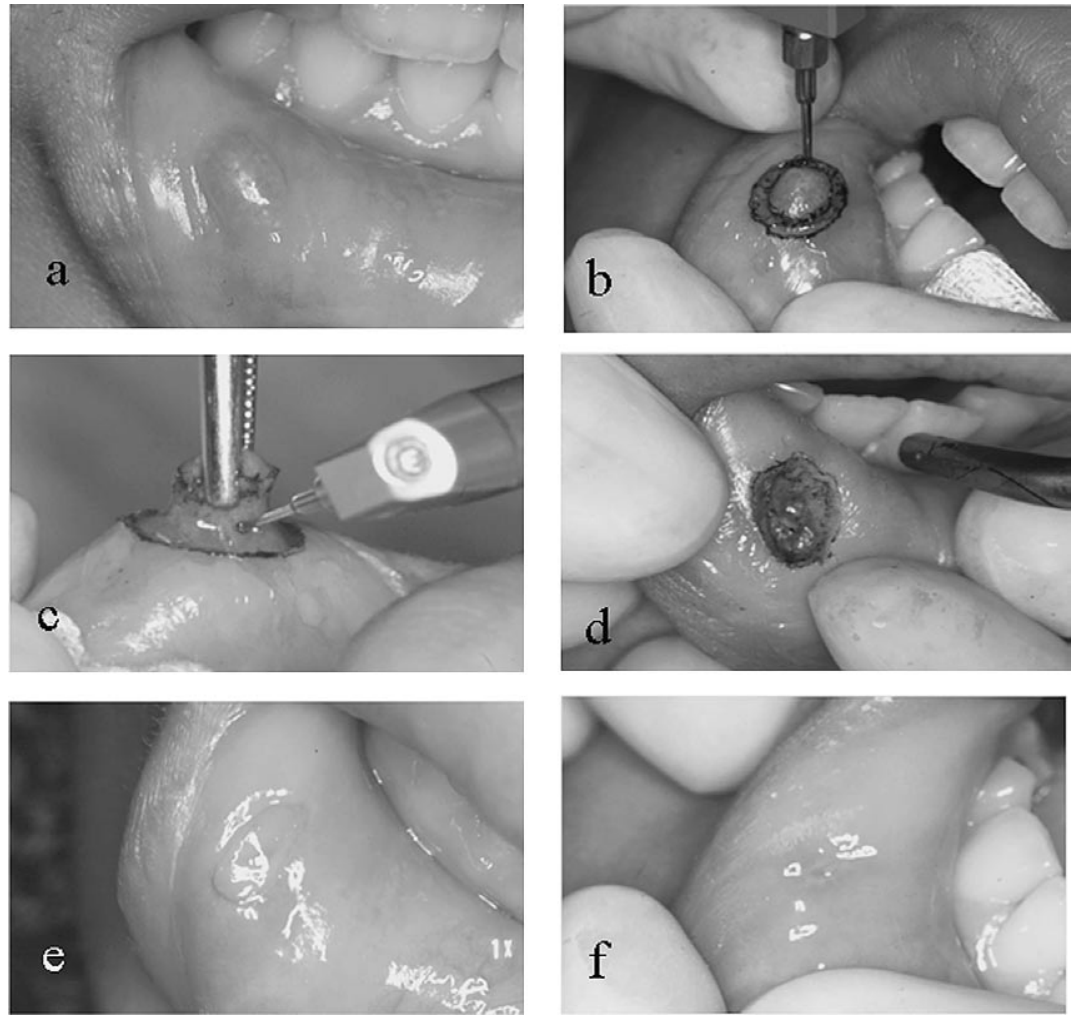

図 7 粘液囊胞摘出 $(13$ 歳 $)$

a. 術前：下口唇に粘液囊胞がみられる。

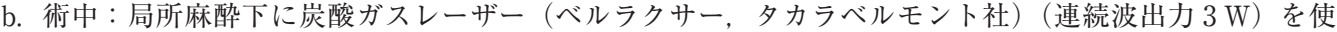
用。襄胞周囲をマーキングする要領で, 深さ $0.5 \mathrm{~mm} \sim 1 \mathrm{~mm}$ 程度切開腺を入れる。

c. 術中：囊胞上部をピンセットで挟んで引き上げ, レーザーを囊胞䡈部に照射すると，容易に摘出できる。

d．囊胞摘出直後：創面の一部に炭化層がみられる。縫合は不要な場合が多い。

e. 4 日後：創面は偽膜で覆われている。術後疼痛はほとんどない。

f. 2 週後：創部は縮小し，周囲に炎症はみられない。

合と同様に，小帯を緊張させ，歯肉よりから照射していく と, 菱形の創面ができる。縫合は行わず，創面の治癒を待 つ9)。炭酸ガスレーザー, Er:YAG レーザーであれば, 2 週間くらいで治癒する。
混合歯列期には粘液囊胞も良く見られる（図 7)。これ は，歯の交換によって，咬傷や粘膜への慢性刺激が起きや すくなるためと考えられている。粘液囊胞の摘出の際は, 䧶胞をつぶさないよう周囲から丸ごとえぐりだす感覚で行 
う ${ }^{15)}$ 。これも, 多くの場合, 開空状態のまま治癒を待つ (図 7)。炭酸ガスレーザー, Er:YAGレーザーは, 2 週間 以内に治癒が見られるが, 半導体レーザーや $\mathrm{Nd}: \mathrm{YAG}$ レーザーでは, 照射時における厚い熱凝固層の出現のため 治癒が遅延する傾向がある。

\section{幼若永久歯列期}

この時期は小学校高学年〜思春期に相当するので, 本人 に自覚させ，齨蝕をつくらないようにすること，できてし まった齟蝕は早めに対応し進行させないこと, そして, 不 幸にも進行してしまった齲蝕に対しては，可能な限り歯䯣 を残すような対応をすること，の3つが目標となる（図 8）。

萌出直後の幼若永久歯では, 切削量は最小限に留めた,

\section{- 予防と啓蒙}

一自己責任を自覚させる

・䠛蝕を進行させない

- 早期発見とMI

- 可能な限り歯髄を残す

- 覆䯣法の可能性

図 8 幼若永久歯列期での目標
いわゆる MI の適用が望まれる。このようなとき, Er:YAG レーザーとフローの良いレジンの組み合わせは有 効である。幼若永久歯では, 軽度のう蝕に見えても, 実際 切削してみると, う蝕が象牙質内に広がっている場合の頻 度は少なくない。したがって, 丁寧な診査によるう蝕の早 期発見，早期対応が欠かせない。

図 9 は, 初期対応が不十分で深く進行してしまった幼若 永久歯う蝕例である。コンポジットレジンによる不良な修 復処置が行われており, う蝕除去後, 一部点状露髄が認め られる。幼若永久歯の歯髄の生命力は強いため, 覆髄法は 有効である。このような症例では, 歯髄の回復, 活性化を 目的に低出力レーザー（He-Ne レーザー, Nd:YAGレー ザー，半導体レーザーにおいて応用可能）を使用し，水酸 化カルシウム製剤を貼付すると速やかな庇蓋硬組織の形成 が得られる ${ }^{8)}$ 。

\section{結語}

小児・若年者の治療では，いかに永久歯をう蝕にさせ ず，かつ正しい位置に萌出させるかが終始一貫した治療目 標になる。そのためには, 乳歯列の段階でう蝕を完治させ ること，幼若永久歯には積極的に予防処置を行うこと，う 蝕は小さいうちに確実に止めること，歯髄は極力保存に努 めること, などが重要である。そして, 治療時に恐怖感や 痛みを与えない安全かつ迅速な治療が要求されるととも に，術後の管理がしやすいことも重要である。アプローチ
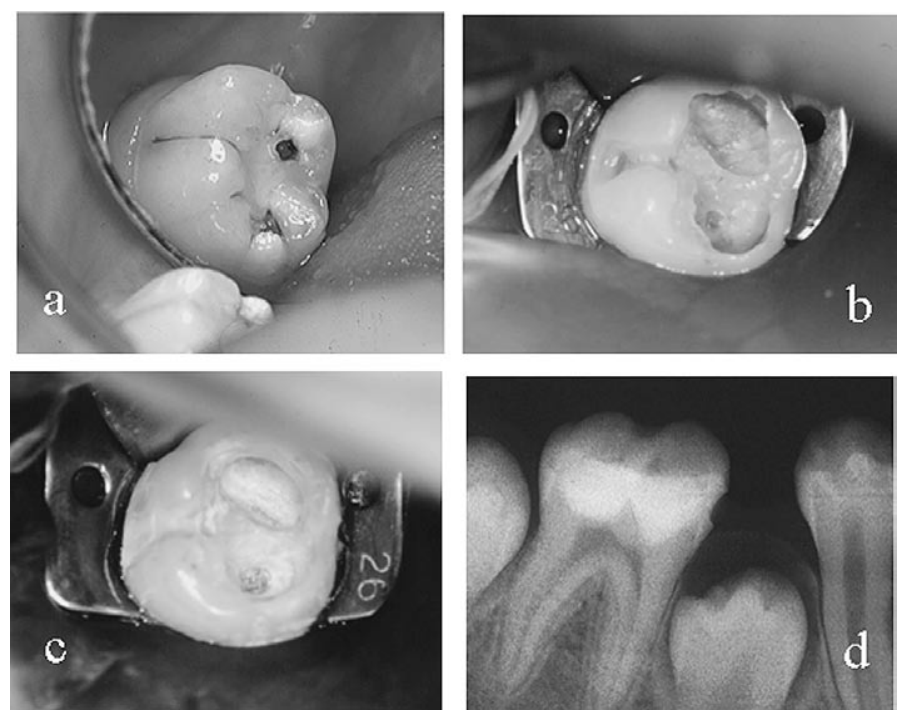

図 9 深在う蝕処置 (7 歳)

a. 術前：下顎第一大臼歯の不良修復物がみられ，大きなう蝕が認められる。

b. 軟化象牙質除去後：一部に点状露髄がみられる。He-Ne レーザー照射後（ベルビーム，タカラベルモント社）（連 続波出力 $6 \mathrm{~mW} ， 2$ 分間照射)，水酸化カルシウム糊剤を貼付し，グラスアイオノマーセメントで暫間修復を行った。

c. 6 カ月後：点状露髄した部位に庇蓋硬組織の形成が認められる。グラスアイオノマーセメントで裏層し，コンポ ジットレジン修復を行った。

d. 2 年後のレントゲン像 : 歯髄腟は連続した硬組織で覆われている。 
の仕方にはいろいろあるが, レーザーは正しく使用すれ ば，通法に比べて迅速かつ低侵襲的に使用できることが多

く，小児・若年者の治療で有効活用される場面は多いと思 われる。

\section{文献}

1）加藤純二, 粟津邦男, 篠木 毅, 守矢佳世子 (編著)：一か らわかるレーザー歯科治療, 第 1 版, 東京, 2003, 医歯薬出 版, $1-25$.

2）守矢佳世子, 加藤純二：Er:YAG レーザー照射時における乳 歯歯質の形態学的変化について. 日レ歯誌, $7: 6-11,1996$.

3) Kato J, Moriya K, Jayawardena JA, et al: A clinical application of Er:YAG laser for cavity preparation in children. J Clin Laser Med Surg, 21 : 151-156, 2003.

4) Hibst R, Keller U: Experimental studies of the application of the Er:YAG laser on dental hard substances. I. measurement of the ablation rate. Lasers Surg Med, 9:338-344, 1989.

5) Keller U, Hibst R: Experimental studies of the application of the Er:YAG laser on dental hard substances. II. Light microscopic and SEM investigations. Lasers Surg Med, 9: 345-351, 1989.

6) Kumazaki M, Toyoda K: Removal of hard dental tissue (cavity preparation) with Er:YAG laser. J Jpn Soc Laser Dent, $6: 16-24,1995$.

7) Thwe TT, Kato J: The comparative histopathological stud- ies of pulpotomized pulp tissues of the developing rat molars with He-Ne laser and Nd-YAG laser irradiation. Pediatric Dent J, $6:$ 69-76, 1996.

8）加藤純二：He-Ne レーザーの小児歯科領域での応用．小児歯 科臨床, $9: 23-26,2004$.

9）加藤純二, 守矢佳世子, 橋本吉明, 他 : 炭酸ガスレーザーを 応用した小児の口腔外科処置一小帯切除術への応用一. 小児 歯誌, $38: 897-905,2000$.

10) Yamamoto H, Sato K: Prevention of dental caries by Nd:YAG laser irradiation. J Dent Res, 59 : 2172-2177, 1980.

11) Fowler BO, Kuroda S: Changes in heated and in laser-irradiated human enamel and their probable effects on solubility. Calc Tiss Int, $38:$ 197-208, 1986.

12) Featherstone JDB, Barrett-Vespone NA, Fried D, et al: $\mathrm{CO}_{2}$ laser inhibition of artificial caries-like lesion progression in dental enamel. J Dent Res, 77 : 1397-1403, 1998.

13）橋本雅子：Nd:YAG レーザー照射によるエナメル質形成不全 歯への耐酸性付与に関する実験的研究. 小児歯誌，28：956967, 1990.

14) Kato J, Moriya K, Jayawardena JA, et al: Prevention of dental caries in partially erupted permanent teeth with a $\mathrm{CO}_{2}$ laser. J Clin Laser Med Surg, 21 : 369-374, 2003.

15）守矢佳世子, 加藤純二：小児の粘液囊胞における炭酸ガス レーザーの応用。 日レ歯誌, $13: 97-103,2002$.

16）加藤純二, Jayawardena JA, Wijeweera RL, 他：炭酸ガス レーザーの小児口腔外科処置への応用一途上国援助活動にお けるレーザー応用一。不病誌，69：34-38， 2002. 